\title{
PENINGKATAN HASIL BELAJAR PESERTA DIDIK MELALUI PENERAPAN MODEL KOOPERATIF TIPE STUDENT TEAM ACHIEVEMENT DIVISION (STAD)
}

\author{
M. Nanang Burhannuddin ${ }^{1 *}$, Dewi Jumiarni ${ }^{1}$, dan Sri Irawati ${ }^{1}$ \\ ${ }^{1}$ Program Studi Pendidikan Biologi, Fakultas Keguruan Dan Ilmu Pendidikan, Universitas Bengkulu \\ E-mail : mnanang.burhanuddin@gmail.com
}

\begin{abstract}
Abstrak
Penelitian ini bertujuan untuk mengetahui hasil belajar peserta didik materi ekosistem dengan menggunakan model pembelajaran kooperatif tipe Student Teams Achievement Division (STAD) pada kelas X MIPA 4 SMAN 4 Kota Bengkulu. Jenis penelitian ini adalah Penelitian Tindakan Kelas (classroom action research) yang dilakukan dalam dua siklus. Setiap siklus terdiri atas empat tahap yaitu perencanaan, pelaksanaan, observasi dan refleksi. Penelitian ini menggunakan metode deskriptif. Subjek dalam penelitian ini yaitu guru dan seluruh peserta didik kelas X MIPA 4 SMAN 4 Kota Bengkulu. Teknik pengumpulan data yang digunakan adalah observasi dan tes. Instrumen penelitian yang digunakan adalah adalah lembar observasi dan lembar dan lembar tes. Hasil belajar ranah kognitif siklus I mendapatkan persentase 74,19 \% (belum tuntas), sedangkan pada siklus II menjadi $87,5 \%$ (tuntas). Hasil belajar psikomotor peserta didik dengan persentase $64,51 \%$ di siklus I berkriteria belum tuntas dan meningkat di siklus II dengan kriteria tuntas dengan persentase $83,87 \%$. Dari hasil penelitian disimpulkan bahwa model pembelajran kooperatif tipe Student Team-AchievementDivision (STAD) dapat meningkatkan hasil belajar peserta didik kelas X MIPA4 SMAN 4 Kota Bengkulu.
\end{abstract}

Kata kunci : Hasil Belajar, Kooperatif tipe Student Team-Achievement Division (STAD).

\begin{abstract}
This resaerch aims to describe the increase in student learning outcomes in the learning process of ecosystem material using cooperative learning models of Student Teams Achievement Division (STAD) type in class of tenth grade of MIPA 4 of SMAN 4 Bengkulu City. This type of research is classroom action research conducted in two cycles. Each cycle consists of four stages, namely planning, implementation, observation and reflection. This research uses a descriptive method. The subjects in this research were teachers and all students of tentth grade of MIPA 4 of SMAN 4 Bengkulu City. Data collection techniques used were observation and tests. The research instruments used were observation sheets and test sheets and sheets. The cognitive learning outcomes of the first cycle get a percentage of $74.19 \%$ (not yet completed), while in the second cycle it becomes $87.5 \%$ (complete). From the results of the research concluded that the cooperative learning model type Student TeamAchievement Division (STAD) can improve the learning outcomes of students of tenth grade of MIPA4 SMAN 4 of Bengkulu City.
\end{abstract}

Keywords: Learning Outcomes, Student Team-Achievement Division (STAD).

\section{PENDAHULUAN}


Pendidikan pada hakikatnya adalah usaha sadar untuk mengembangkan kepribadian dan kemampuan di dalam dan di luar sekolah dan berlangsung seumur hidup dan dilaksanakan dalam lingkungan keluarga, sekolah dan masyarakat. Untuk meningkatkan kualitas manusia dan meningkatkan mutu pendidikan berbagai usaha telah dilaksanakan pemerintahan, usaha tersebut antara lain: penyempurnaan kurikulum, pengadaan sarana dan prasarana pendidikan, pelatihan guru dan program-program lain yang bersifat dapat meningkatkan mutu pendidikan.

Pendidikan IPA menekankan pada pemberian pengalaman langsung untuk mengembangkan potensi peserta didik menjelajahi dan memperoleh pemahaman yang lebih mendalam tentang dirinya sendiri dan alam sekitar. Dalam proses pembelajaran IPA, keaktifan peserta didik merupakan inti dari pola belajar. Biologi sebagai salah satu cabang ilmu pendidikan di bidang pengetahuan alam menawarkan berbagai pengalaman siswa dalam menjadi permasalahan, meneliti dan menyimpulkan suatu permasalahan yang berkaitan dengan alam untuk memahamiproses dan konsep sains (Kurniasih, 2015).

Pembelajaran biologi di sekolah menengah diharapkan dapat menjadi wahana bagi peserta didik untuk mempelajari diri sendiri dan alam sekitar serta proses pengembangan lebih lanjut dalam penerapannya di kehidupan seharihari. Penting sekali bagi setiap guru memahami sebaik-baiknya tentang proses belajar siswa, agar dapat memberikan bimbingan dan menyediakan lingkungan belajar yang tepat dan serasi bagi siswa (Hamalik, 2010).

Berdasarkan hasil wawancara dan observasi awal yang di lakukan terhadap proses pembelajaran biologi di kelas $X$
MIPA 2 SMAN 4 Kota Bengkulu di peroleh beberapa informasi yaitu: pembelajaran masih bersifat konvensional, di mana guru menggunakan model pembelajaran ceramah yang proses pembelajarannya masih berpusat pada guru. Padahal berdasarkan kurikulum 2013, peserta didik dituntut untuk aktif dalam proses pembelajaran. Pada proses pembelajaran yang telah dilakukan, guru belum menerapkan kelompok belajar (learning community) dengan optimal, sehingga siswa lebih banyak diam, bosan atau tidak fokus saat berlangsungnya pembelajaran. Terbukti dari nilai ulangan akhir semester siswa dalam mata pelajaran biologi yang belum tuntas KKM sebanyak 10 orang dari 30 orang siswa atau yang tuntas hanya mencapai 33,33\%. Dengan demikian ketidak tuntasan klasikal mencapai $66,67 \%$.

Salah satu faktor penyebab rendahnya hasil belajar biologi saat ini berkaitan dengan strategi pembelajaran yang dilaksanakan. Dalam proses pembelajaran guru terlalu mendominasi peserta didik sehingga keterlibatan peserta didik dalam proses pengajaran sangat kurang. Untuk meningkatkan aktivitas dan hasil belajar siswa dibutuhkan strategi belajar yang mampu melibatkan seluruh siswa dalam proses pembelajaran. Starategi ini dituntut untuk melibatkan siswa sebagai subjek dalam pembelajaran dibandingkan sebagai objek pembelajaran.

Salah satu model pembelajaran yang berkembang saat ini adalah model pembelajaran kooperatif. Pembelajaran kooperatif adalah model pembelajaran yang dirancang agar siswa dapat menyelesaikan tugasnya secara kelompok, sehingga membantu siswa untuk memperlihatkan rasa tanggung jawab terhadap kelompoknya. Menurut Rusman (2010), pada dasarnya cooperative learning mengandung pengertian sebagai 
suatu sikap atau perilaku bersama dalam bekerja atau membantu di antara sesama dalam struktur kerja sama yang teratur dalam kelompok, yang terdiri dari dua orang atau lebih di mana keberhasilan kerja sangat dipengaruhi keterlibatan dari setiap anggota kelompok itu sendiri.

Ada beberapa tipe model pembelajaran kooperatif, salah satunya adalah pembelajaran kooperatif tipe Student Teams Achievement Division (STAD). Metode ini dipandang sebagai yang paling sederhana dan paling langsung dari pendekatan pembelajaran kooperatif. Alma (2009) menyatakan bahwasanya Student Teams-Achievement Division (STAD) terdiri dari lima komponen utama yaitu : 1) presentasi kelas, 2) tim, 3) kuis, 4) skor kemajuan individual, 5) rekognisi tim. Berikut ini beberapa keunggulan pembelajaran kooperatif tipe Student Teams-Achievement Divisions (STAD) menurut Kurniasih (2015) antara lain: 1) Karena dalam kelompok peserta didik dituntut untuk aktif sehingga dengan model ini peserta didik dengan sendirinya akan percaya diri dan meningkat kecakapan individunya, 2) Interaksi sosial yang terbangun dalam kelompok, karena dengan sendirinya peserta didik belajar dalam bersosialisasi dengan lingkungannya (kelompok).

Hasil penelitian Riyadi, dkk (2015) menunujukkan bahwa penerapan metode STAD meningkatkan hasil belajar peserta didik Siswa Kelas X-F SMA Negeri 1 Tangen Sragen dengan ketuntasan klasikal 70,52\% menjadi $73,02 \%$. Berdasarkan latar belakang diatas, maka peneliti melakukan penelitian dengan judul "Penerapan Model Kooperatif tipe Student Teams Achievement Division (STAD) untuk meningkatkan aktifitas dan hasil belajar peserta didik, pada materi Biologi dengan kompetensi dasar (KD) 3.10 Menganalisis komponen-komponen ekosistem dan interaksi antar komponen.

\section{METODE}

Jenis penelitian yang digunakan dalam penelitian ini yaitu penelitian tindakan kelas (PTK) yang didasarkan kepada model Kemmis dan Mc Taggart (Wardani, dkk, 2005). Metode penelitian yang digunakan dalam penelitian ini adalah metode deskriptif (Sudjana, 1989).

Subyek penelitian ini adalah guru dan peserta didik. Guru dalam penelitian ini adalah peneliti. Sedangkan peserta didik dalam penelitian ini adalah seluruh peserta didik kelas X MIPA 4 SMAN 4 Kota Bengkulu Peserta didik dengan jumlah 36 orang yang terdiri dari 16 orang laki-laki dan 20 orang perempuan.

Teknik yang digunakan untuk mengumpulkan data pembelajaran dalam penelitian ini adalah teknik observasi dan tes. Sedangkan instrumen yang digunakan adalah lembar observasi dan lembar tes. Lembar observasi psikomotor peserta didik digunakan untuk mengobservasi penilaian hasil belajar peserta didik ranah psikomotor dalam kegiatan pembelajaran dengan model kooperatif Student TeamsAchievement Divisions (STAD). Lembar tes terdiri dari soal-soal pilihan ganda yang digunakan untuk mengukur hasil belajar ranah kognitif peserta didik. Bentuk tes yang di gunakan dalam penelitian ini adalah tes objektif yaitu tes yang dalam pemeriksaannya dapat dilakukan secara objektif yang akan diberikan pada akhir pembelajaran.

Tes kognitif dilakukan setiap akhir siklus yang bertujuan untuk mengetahui hasil belajar peserta didik pada ranah pengetahuan. Ketuntasan klasikal dari data nilai hasil belajar (kognitif) peserta didik kelas setiap siklus maka dapat diketahui menggunakan rumus sebagai berikut : 
$q=\frac{\sum \text { peserta didik yang tuntas belajar }}{\sum \text { siswa }} \times 100 \%$

(Sudjana, 2012).

Keterangan :

$\mathrm{q}=$ ketuntasan belajar klasikal

$\sum$ peserta didik yang tuntas belajar $=$ jumlah peserta didik yang memperoleh nilai $\geq 75$

$\sum$ peserta didik $=$ jumlah seluruh peserta didik

Menurut ketentuan yang ditetapkan SMAN 4 Kota Bengkulu, peserta didik yang dikatakan tuntas belajarnya apabila $\geq 80 \%$ peserta didik telah memperoleh nilai $\geq 76$.

Data hasil belajar psikomotorik dihitung menggunakan rumus sebagai berikut (Panduan penilaian untuk SMA tahun 2015) :

Nilai $=\frac{\text { jumlah skor yang diperoleh }}{\text { jumlah skor maksimum }} \times 100$ (Sudjana, 2012).

Menurut ketentuan yang ditetapkan di SMAN 4 Kota Bengkulu hasil belajar psikomotorik peserta didik dikatakan tuntas pada mata pelajaran Biologi apabila mencapai nilai $\geq 75$ dengan ketuntasan belajar klasikal yaitu $\geq 80 \%$.

\section{HASIL DAN PEMBAHASAN}

Adapun hasil dari pelaksanan post test hasil belajar ranah kognitif peserta didik pada siklus I dan II menghasilkan beberapa data sesuai dengan Gambar 1 :

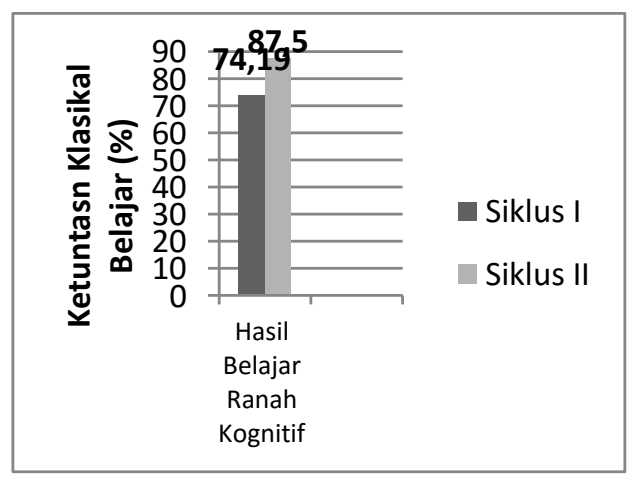

Gambar 1. Diagram Persentase Ketuntasan Klasikal Hasil Belajar Peserta Didik Ranah Kognitif Siklus I dan II
Dari diagram diatas dapat dilihat bahwa rata-rata nilai peserta didik dari siklus I ke siklus II mengalami peningkatan yaitu dari $74,19 \%$ menjadi $87,5 \%$. Sedangkan nilai ketuntasan belajar klasikal pada siklus ke dua menunjukkan bahwa proses pembelajaran biologi kelas X MIPA 2 SMAN 4 Kota Bengkulu telah mencapai ketuntasan belajar klasikal. Adapun skor peningkatan klasikal dari siklus I ke siklus II adalah 13,31\%.

Kemudian hasil dari pelaksanan penilaian hasil belajar ranah psikomotor peserta didik pada siklus I dan II dapat dilihat pada Gambar 2 :

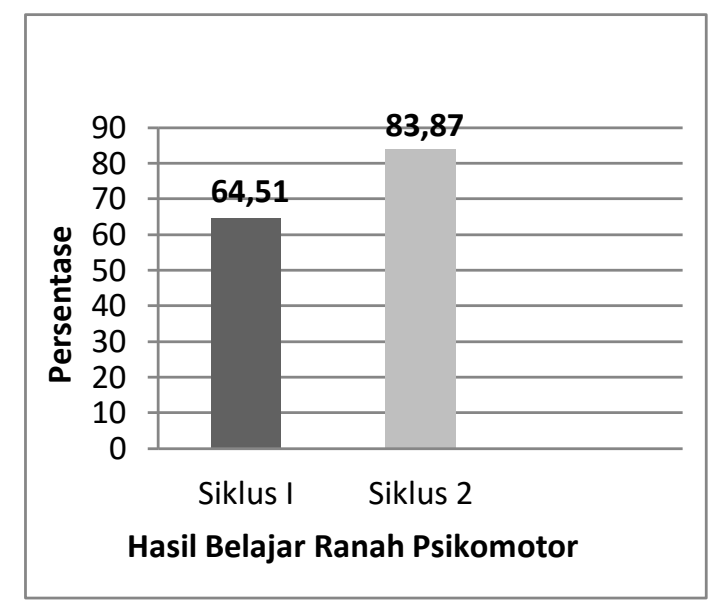

Gambar 2. Diagram Persentase Hasil Belajar Peserta Didik Ranah Psikomotor Siklus I dan II

Diketahui bahwa hasil belajar peserta didik ranah psikomotor pada siklus I, memiliki hasil data persentase peserta didik dengan kriteria baik yaitu $64,51 \%$. Sedangkan, pada siklus II memiliki hasil data persentase peserta didik dengan kriteria baik yaitu $83,87 \%$

Pada tahap kegiatan inti pembelajaran, terdapat beberapa aktivitas guru dan aktivitas peserta didik dalam setiap sintaks pembelajaran dengan model pembelajaran kooperatif Student TeamsAchievement Divisions (STAD) sebagai berikut : 
1) Menyampaikan Tujuan dan Memotivasi Siswa

Pada tahap satu yang telah dilakukan, meskipun penyampaian apresepsi telah dilakukan dengan baik namun pada kegiatan ini masih ada peserta didik yang kurang merespon apresepsi yang diberikan oleh guru sehingga pengamat menilai cukup pada lembar deskriptor aktivitas peserta didik. Hal ini dikarenakan masih banyak peserta didik yang kurang memperhatikan atau menanggapi apresepsi yang di berikan oleh guru dimana peserta didik hanya memperhatikan dan tidak mencatat tujuan pembelajaran yang dijelaskan oleh guru. Seharusnya guru harus pandai mengatur siswa untuk disiplin agar mereka bisa mengikuti proses pembelajaran dengan baik.

Dari pengamatan yang dilakukan hal ini sesuai dengan pernyataan Gagne dan Wikle dalam Isjoni (2011) bahwa cara guru memberikan motivasi kepada peserta didik sangat berpengaruh kepada keaktifan peserta didik itu sendiri. Dan selaras juga dengan pendapat Wardana (2017) dalam penelitian nya peserta didik sadar akan tujuan pembelajaran yang harus dicapai dan bersedia melibatkan diri, maka peserta didik akan mencapai fase motivasi. Peran guru dalam hal ini adalah untuk meningkatan minat belajar peserta didik, memotivasi belajar peserta didik dan menyadarkan peserta didik akan tujuan pembelajaran yang harus dicapai.

2) Menyajikan Informasi

Pada tahap pembelajaran yang dialakukan di siklus I dan II, guru mencatat point-point penting mengenai materi pembelajaran yang disampaikan dipapan tulis. Di siklus II guru melibatkan peserta didik untuk menyampaikan hal-hal yang diketahui peserta didik berkaitan dengan materi pembelajaran yang dijelaskan oleh guru.
Pada tahap ini kemampuan guru untuk berkomunikasi dengan baik terhadap peserta didik dalam menyajikan materi pembelajaran merupakan salah satu faktor yang dapat membuat peserta didik tersebut merespon dengan baik pembelajaran yang diberikan. Hal ini sejalan dengan pendapat Sanjaya (2010) guru dituntut agar memiliki kemampuan dalam berkomunikasi dan berinteraksi dengan peserta didik secara efektif, sehingga dapat memudahkan peserta didik menangkap pesan dalam pembelajaran yang telah dilaksanakan.

3) Mengorganisasikan Peserta Didik dalam Kelompok Belajar.

$$
\text { Pada kegiatan ini guru }
$$

menempatkan siswa ke dalam 6 kelompok heterogen yang terdiri 5-6 orang peserta didik dan membimbing peserta didik untuk berada pada kelompoknya masing-masing. Pada siklus I sebelumnya guru dan pengamat telah memilih dan membagi peserta didik kedalam kelompok belajar secara heterogen yang terdiri atas 5-6 anggota per tim, sehingga ketika pembelajaran dimulai peserta didik telah mengetahui kelompok nya masing-masing.

Hal ini sesuai dengan pendapat (Trianto, 2009) didalam kelas kooperatif peserta didik belajar bersama dalam kelompok-kelompok kecil yang terdiri dari 4-6 orang peserta didik yang sederajat tetapi heterogen dengan kemampuan, jenis kelamin, suku/ras, dan satu sama lain saling membantu. Tujuan dibentuknya kelompok tersebut adalah untuk memberikan kesempatan kepada peserta didik untuk dapat terlibat secara aktif dalam proses berpikir dalam kegiatan pembelajaran. Selama bekerja dalam kelompok, tugas anggota kelompok adalah mencapai ketuntasan materi yang disajikan oleh guru, dan saling membantu teman sekelompoknya untuk mencapai ketuntasan belajar. 


\begin{abstract}
Maka dengan adanya kegiatan diskusi kelompok sintaks model pembelajaran ini akan mendukung terhadap peningkatakan hasil belajar peserta didik. Hal ini didukung oleh penelitian yang dilakukan oleh Herviza,dkk (2018), yang menyatakan bahwa salah satu faktor peningkatan hasil belajar peserta didik pada proses pembelajaran adalah kegiatan diskusi dan saling bekerjasama antar peserta didik.
\end{abstract}

4) Membimbing Kelompok Bekerja dan Belajar

Pada tahap ini peserta didik belajar dalam kelompok yang telah dibentuk. Peneliti memberikan lembaran kerja pada masing- masing kelompok, dalam kerja kelompok setiap anggota dalam satu kelompok saling memberikan kontribusi sehingga semua anggota dalam satu kelompok dapat menguasai materi dengan baik. Selama kegiatan kelompok ini peneliti berkeliling kesemua kelompok dengan memberikan bimbingan, dorongan dan bantuan jika ada kelompok yang mengalami kesulitan.

Maka dapat disimpulkan bahwa tahap membimbing kelompok bekerja dan belajar yang dilakukan oleh guru, akan meningkatkan keaktifan peserta didik sehingga akan berdampak pada hasil belajar. Kebanyakan peserta didik akan aktif dalam kelompok jika ia diamati langsung oleh guru. Sesuai dengan pendapat Astuti (2017) bahwa kerja kelompok yang efektif biasanya dipengaruhi oleh sejauh mana kelompok tersebut merefleksikan proses kerjasama mereka. Sambil mengobsevasi setiap kelompok kooperatif, guru dapat melihat apa yang dipahami dan tidak dipahami oleh peserta didik tentang tata cara mengerjakan tugas dengan benar.

5) Evaluasi

Pada tahap ini siswa diberi lembar soal tes (Kuis) berupa soal obyektif yang terdiri dari 10 soal pilihan ganda. Soal tersebut dikerjakan secara individu. Guru berkeliling untuk memantau peserta didik dan mengingatkan peserta didik untuk tidak saling bekerja sama dalam mengerjakan tes, dimana tes digunakan untuk mengukur pemahaman peserta didik mengenai materi yang dipelajari selama proses pembelajaran berlangsung.Tes yang dilakukan untuk melihat hasil belajar biologi peserta didik yang mencakup kompetensi pemahaman konsep. Kompetensi pemahaman konsep peserta didik yang dinilai yaitu kemampuan kognitif.

6) Memberikan penghargaan

$$
\text { Pada tahap ini pemberian }
$$
penghargaan dilakukan pada akhir pembelajaran dimana guru memberikan penghargaan kepada siswa yang mendapatkan nilai kuis tertinggi dan memberikan kepada kelompok kerja yang mendapatkan nilai tertinggi antar setiap kelompok. Menurut Huda (2011) perolehan nilai kuis setiap anggota menentukan skor yang diperoleh oleh kelompok mereka.

Pada siklus I ada beberapa aspek yang masih memperoleh kriteria penilaian cukup yg diberikan oleh kedua pengamat. Dimana guru hanya memberikan pujian dan hadiah kepada 1 kelompok peserta didik yang memperoleh nilai kuis tertinggi. Namun pada aspek ini di siklus II kedua pengamat memberikan nilai baik dikarenakan guru memberikan pujian dan hadiah kepada kelompok peserta didik yang memperoleh nilai tertinggi dan memberikan kepada satu orang peserta didik yang mendapatkan nilai kuis tertinggi.

Hal ini selaras dengan penelitian yang pernah dilakukan sebelumnya oleh Sigalingging (2016) di temukan hasil dari penelitian ini yaitu penghargaan berpengaruh positif terhadap aktivitas 
peserta didik. Penelitian ini menunjukkan bahwa dengan pemberian penghargaan dapat meningkatkan kinerja peserta didik.

\section{PENUTUP}

Simpulan

Adapun kesimpulan dalam penelitian tindakan kelas ini adalah sebagai berikut :

Penerapan model pembelajaran kooperatif Student Team Achieviment Division (STAD) dapat meningkatkan hasil belajar biologi peserta didik kelas X MIPA 2 SMAN 4 Kota Bengkulu pada pokok bahasan ekosistem. Hal ini dapat dilihat dari peningkatan nilai persantase klasikal hasil belajar peserta didik dari siklus I sebesar $74,19 \%$ naik menjadi $87,5 \%$ pada siklus II. Adapun skor peningkatan klasikal dari siklus I ke siklus II adalah 13,31\%

\section{Saran}

Berdasarkan penelitian yang telah dilakukan, beberapa saran yang dapat dianjurkan yaitu :

1) Diharapkan kepada guru mata pelajaran Biologi kelas X MIPA 2 SMAN 4 Kota Bengkulu dapat menggunakan model pembelajaran kooperatif tipe STAD sebagai alternatif model pembelajaran yang baik dan tepat untuk digunakan pada materi ekosistem dalam upaya peningkatan hasil belajar peserta didik.

2) Diharapkan untuk peneliti selanjutnya agar dapat lebih mengoptimalkan tiap sintaks model pembelajaran kooperatif tipe STAD dan dapat memanajemen waktu dengan sebaik mungkin agar mendapatkan hasil yang maksimal.

\section{DAFTAR PUSTAKA}

Alma, B. 2007. Model-model Pembelajaran Inovatif Berorientasi Konstruktivitistik, Konsep, Landasan Teoritis-Praktis dan
Implementasinya. Bandung : Alfabeta.

Astuti, Wiwik Wiji. 2017. Perbandingan Hasil Belajar Biologi Antara Model Pembelajaran Kooperatif Tipe Student Teams Achievement Division (STAD) Dan Mode Pembelajaran Kooperatif Tipe Think Pair Share (TPS) Siswa Kelas XI IPA SMA Negeri 5 Makassar. Jurnal Biotek. Vol (5) 2 : 236. https://journal.uin-alauddin.ac.id /index.php/biotek/article/downloa d/4291/4013. Diakses: 20 Juli 2019.

Depdikbud. 1991. Kamus Besar Bahasa Indonesia, Jakarta: Balai Pustaka.

Hamalik, O. 2010. Proses Belajar Mengajar. Jakarta: PT Bumi Aksara.

Herviza, Meftha,. Jumiarni, Dewi,. dan Irawati, Sri. 2018. Peningkatan Hasil Belajar Melalui Model Kooperatif Tipe Jigsaw pada Peserta Didik Smpn 3 Kaur. Jurnal Pendidikan dan Pembelajaran Biologi. Vol 2(2): 94101. (Online). https://ejournal.unib .ac.id/index.php/ippb/article/view/ 6813. 20 Juli 2019.

Huda, Miftahul. 2011. Cooperative Learning. Yogyakarta: Pustaka Belajar.

Isjoni. 2011.Pembelajaran Kooperatif. Yogyakarta: Pustaka Pelajar.

Koes, S. 2003. Strategi Pembelajaran. Jurusan Fisika FP MIPA UM. Malang.

Kurniasih, I., Berlin, S. (2015). Ragam Pengembangan Model Pembelajaran. Jakarta: Kata Pena. 
Rusman. (2010). Model-model Pembelejaran Inofatif. Jakarta : PT Raja Grafindo.

Riyadi, Nanang,. Indrowati, Meti,. dan Sugiharto, Bowo. 2015 . Peningkatan Hasil Belajar Biologi Dengan Penerapan Model Kooperatif Tipe STAD Pada Siswa Kelas X-F SMA Negeri 1 Tangen Sragen Tahun Pelajaran 2013/2014. Jurnal Bio-Pedagogi. https://jurnal. uns.ac.id/pdg/article/view/5360/47 58. Diakses: 20 Juli 2019.

Sanjaya, Wina. (2010). Strategi Pembelajaran Berorientasi Standar Proses Pendidikan. Jakarta : Prenada Media Group.

Sigalingging, Pujiono,. dan Sipayung, Mariaty. 2016. Upaya Peningkatan Hasil Belajar Biologi dengan Kombinasi Model Pembelajaran Kooperatif Tipe STAD dan Teknik Mencatat Mind Map di Kelas XI IPA SMA Negeri 1 Parbuluan T.P 2014/2015. Jurnal Pelita Pendidikan. Vol (4)1 : 108. https://jurnal.unimed.ac.id/2012/in dex.php/pelita/article/view/3687/7 322. Diakses: 20 Juli 2019.
Sudjana, N. Ibrahim. 2012. Penilaian Hasil Proses Belajar Mengajar. Bandung : Remaja Rosdakarya.

Sudjana,N. Ibrahim. 1989. Penelitian dan penilaian pendidikan. Bandung : Sinar Baru.

Wardana, Ika,. Banggali, Tinggi,. dan Husain, Halimah. 2017. Penerapan Model Pembelajaran Kooperatif Tipe Student Team Achivement Division (STAD) untuk Meningkatkan Hasil Belajar Siswa Kelas XI IPA Avogadro SMA Negeri 2 Pangkajene. Jurnal Chemica Vol(18)1 : 76-84. https://ojs.unm. ac.id/chemica/article/download/46 78/2684 . Diakses: 20 Juli 2019.

Wardani. 2005. Penelitian Tindakan Kelas. Jakarta : Universitas Terbuka. 